\title{
Physiological cost of induced resistance in cotton plants at different nitrogen levels
}

\author{
Maria Angélica Guimarães Barbosaㄹ, Delson Laranjeira², Rildo Sartori Barbosa Coelho ${ }^{3}$
}

\begin{abstract}
${ }^{1}$ Embrapa Semi-Árido. BR 428, Km 152, caixa postal 23, Petrolina, PE, Brasil, E-mail: angelica.guimaraes@ cpatsa.embrapa.br ${ }^{2}$ Universidade Federal Rural de Pernambuco - UFRPE. Departamento de Agronomia - Fitossanidade, CEP 52171-900, Recife, PE, Brasil ${ }^{3}$ Empresa Pernambucana de Pesquisa Agropecuária - IPA. Sede, CEP 50761-000, Recife, PE, Brasil Corresponding Author: Maria Angélica Guimarães Barbosa Data de chegada: 16/10/2006. Aceito para publicação em: 12/03/2008.
\end{abstract}

\section{ABSTRACT}

Barbosa, M.A.G.; Laranjeira, D.; Coelho, R.S.B. Custo fisiológico da resistência em algodoeiro sob diferentes níveis de nitrogênio. Summa Phytopathologica, v.34, n.4, p.338-342, 2008

A indução de resistência pelo uso de indutores químicos tem resultado algumas vezes em custo fisiológico para a planta. A resistência induzida em algodoeiro foi avaliada quanto ao custo fisiológico em uma linhagem suscetível a Colletotrichum gossypii var. cephalosporioides (CNPA GO 2002 - 7997) que foi cultivada em substratos com dois níveis de nitrogênio e receberam duas aplicações dos indutores acibenzolar-S-metil (ASM), ácido jasmônico (AJ) e Agro-Mós ${ }^{\circledR}$ (AM). As plantas foram avaliadas quanto à altura (AP), comprimento de internódio (CI), biomassa fresca da parte aérea (BFPA), biomassa fresca da raiz (BFR), biomassa seca da parte aérea (BSPA) e biomassa seca da raiz (BSR). Também foi determinada a atividade das enzimas fenilalanina amônia liase (PAL) e peroxidase. As plantas tratadas com ASM apresentaram alto custo fisiológico com acentuada redução na AP, BFPA e BSPA, enquanto as tratadas com AJ mostraram aumento significativo na BSPA, além de não diferirem significativamente na AP e CI. No substrato suplementado com nitrogênio, todos os indutores diferiram da testemunha quanto ao comprimento de internódio, apesar de não diferirem entre si, enquanto no substrato sem adição de nitrogênio apenas ASM e AM apresentaram diferença significativa entre si. Foram constatadas correlações significativas $(\mathrm{P} \leq 0,05)$ para a maioria das variáveis analisadas sendo as maiores correlações verificadas entre BFPA e BSPA $(0,94)$, CI e AP $(0,74)$, BFPA e AP $(0,70)$ e BSPA e AP $(0,70)$. ASM induziu a menor atividade de PAL, diferindo significativamente dos demais tratamentos. A maior atividade de peroxidase foi verificada em ASM, que diferiu significativamente da testemunha, no entanto, $\mathrm{AM}$ e AJ apresentaram atividade para esta enzima menor que a testemunha, não ficando confirmada a indução de resistência nesses dois tratamentos.

Palavras-chave adicionais: acibenzolar-S-metil, ácido jasmônico, Agro-Mós ${ }^{\circledR}$, fenilalanina amônia liase e peroxidase.

\section{RESUMO}

Barbosa, M.A.G.; Laranjeira, D.; Coelho, R.S.B. Physiological cost of induced resistance in cotton plants at different nitrogen levels. Summa Phytopathologica, v.34, n.4, p.338-342, 2008

Resistance induction through the use of chemical inducers often results in physiological costs to the plant. In this study, induced resistance in cotton plants was evaluated with regard to physiological costs in a cultivar susceptible to Colletotrichum gossypii var. cephalosporioides (CNPA GO 2002 - 7997). Plants were cultivated in substrates with two levels of nitrogen and received two applications of acibenzolar-S-methyl (ASM), jasmonic acid (JA) and Agro$\operatorname{Mos}^{\circledR}(A M)$ disease resistance inducers. Plant height $(H)$, internodal length (IL), shoot fresh weight (SFW), root fresh weight (RFW), shoot dry weight (SDW) and root dry weight (RDW) were evaluated. The activity of the phenylalanine ammonia lyase (PAL) and peroxidase (POX) was also determined. The plants treated with ASM presented high physiological costs with an accentuated reduction in $\mathrm{H}, \mathrm{SFW}$ and $\mathrm{SDW}$, whereas those treated with JA exhibited a significant increase in SDW, and did not significantly differ from $\mathrm{H}$ and IL. In the potting mix supplemented with nitrogen, all inducers differed from the control treatment regarding to internodal length, whereas only ASM and AM presented a significant difference between one another in the potting mix without the addition of nitrogen. Significant correlations $(\mathrm{P}=0.05)$ were found for most of the variables analyzed, with greater correlations observed between SFW and SDW (0.94); IL and H (0.74); SFW and H (0.70); and SDW and $H(0.70)$. ASM induced the least amount of PAL activity, significantly differing from the remaining treatments. Greater POX activity was observed in ASM, which significantly differed from the control. AM and JA, however, presented lower activity than the control with regard to these enzymes, and it was not possible to confirm induction resistance in these two treatments.

Keywords: acibenzolar-S-methyl, jasmonic acid, Agro-Mos, phenylalanine ammonia lyase and peroxidase.

There is a large number of challenges regarding the control of plant diseases in the $21^{\text {st }}$ century. The use of chemicals has currently become restricted due to problems caused to the environment, as well as the high costs involved and the potential risk of the emergence of pathogen 
populations that are resistant to the chemical products. The use of resistant cultivars is currently the most recommended control method. In numerous cultivars, however, resistance is associated to undesirable agronomic characteristics or short durability due to the appearance of virulent pathogen populations. Thus, induced resistance has emerged as an important alternative in the control of pathogens. This strategy is based on the activation of natural defense mechanisms in plants and offers efficient and economical control against a gamut of pathogens $(16,17,23)$. However, the use of inducers does not always result in production of benefits, as resistance activation places high energy demands on the plant $(8$, 24). There is evidence of the physiological cost of plant resistance to herbivores, but it has yet to be determined whether induced resistance to pathogens causes a relevant physiological costs to plants (8).

The physiological costs of resistance is the negative effect resulting from the expression of resistance under certain conditions in which such a resistance is not necessary, such as in the absence of a pathogen (8). These negative effects may harm the symbiotic interactions with microorganisms that are beneficial to the plant, such as mycorrhizas, as well as interfere in resistance to insects even when making the plant more resistant to pathogens. Negative effects can also redirect metabolites and energy used for growth and other important plant processes, including defense responses (11).

The "cost of defense" theory has emerged from negative correlations between maximum plant growth rate and the concentration of secondary compounds related to the defense of biotic factors, such as cellulose, hemicellulose, terpenoids and phenolic compounds (13).

Salicylic acid (SA) and jasmonic acid (JA) are two important compounds with distinct metabolic pathways regarding to induced resistance. Both compounds are hormones involved in plant development processes, such as flower and fruit formation. A number of relevant effects in the increase of JA and SA may result in changes to these functions due to the defensive role these compounds play (10).

Little is yet known regarding the influence of genotype and environmental conditions on the expression of induced resistance (24). Interactions between abiotic stress and resistance are only just beginning to be investigated. In evaluating seed production in plants treated with resistance inducers and subjected to limiting environmental conditions, such as a low supply of nitrogen, water stress and competition with other plants, Dietrich et al. (8) observed physiological cost in some cases, but not in others, with the occurrence of an increase in seed production in plants treated with inducers in comparison to untreated plants, depending on the combination of environmental factors. According to Dietrich et al. (7), nitrogen is one of the principal factors that limit plant growth and strongly affect the expression of resistance, whether constitutive or induced.

Therefore, the aim of the present study was to assess the physiological cost of induced resistance in cotton plants cultivated with two different nitrogen levels.

\section{MATERIALAND METHODS}

The experiment was conducted in a greenhouse, where cotton seeds from the cultivar CNPA GO 2002 - 7997 (received from Embrapa Algodão), which were susceptible to Colletotrichum gossypii South var. cephalosporioides Costa, were sown in $2.8 \mathrm{~L}$ plastic pots containing a potting mix made up of three parts soil $(\mathrm{pH}=6.4 ; \mathrm{P}=4$ $\left.\mathrm{mg} / \mathrm{dm}^{3} ; \mathrm{K}=0.88 \mathrm{c} / \mathrm{mol}_{\mathrm{c}} / \mathrm{dm}^{3} ; \mathrm{Ca}=3.10 \mathrm{c} / \mathrm{mol}_{\mathrm{c}} / \mathrm{dm}^{3}\right)$ and one part of humus, sterilized with methyl bromide. Two potting mixes with nitrogen were used: a substrate without fertilization $(\mathrm{N}=0.07 \%)$ and a substrate with the supplementation of $0.06 \mathrm{~g}$ of urea/pot, mixed according to a recommendation based on the substrate analysis (9).

The acibenzolar-S-methyl (ASM), JA and Agro-Mos ${ }^{\circledR}$ (AM) inducers were sprayed on the foliage at 15 and 25 days after the emergence of the plants at dosages of $100 \mathrm{mg}$ i.a.L $\mathrm{L}^{-1}, 20 \mu \mathrm{L}$ p.c. $\mathrm{L}^{-1}$ and $2 \mathrm{~mL}$ p.c. $\mathrm{L}^{-1}$, respectively.

The experimental design was a completely randomized in a $2 \times 4$ factorial arrangement represented by two nitrogen levels, three inducers and a control treatment (plants sprayed with water). Each treatment five replications, with each experimental unit made up of four plants.

\section{Physiological cost of resistance induction}

At 45 days after emergence, the plants were assessed with regard to height (H), internodal length (IL), shoot fresh weight (SFW), root fresh weight (RFW), shoot dry weight (SDW) and root dry weight (RDW). Height was measured with a ruler from the surface of the soil to the highest point of the plant. IL was determined by the distance between the cotyledonary leaves and the first pair of definitive leaves. The SFW and RFW were quantified after removing the plants from the pots, separating the root system from the shoot at the transition region between the root and the stem base and weighing them separately on a scale to two decimal points. The SDW and RDW were determined after the plants were placed in paper bags and subjected to drying in a lab stove at $37^{\circ} \mathrm{C}$. Weighing was performed after the plants had been removed from the greenhouse and had reached room temperature.

Data were submitted to analysis of variance and averages were compared using the Duncan test $(\mathrm{P}=0.05)$. The correlation between variables was assessed using the Pearson correlation analysis $(\mathrm{P}=0.05)$. Analyses were performed with the help of the SAEG program (Statistical and Genetic Analysis System of the Universidade Federal de Viçosa, Viçosa - MG, Brazil 2003).

\section{Enzymatic Determination}

Leaf samples of $1.0 \mathrm{~g}$ (corresponding to each treatment) were collected at 45 days after plant emergence and were ground in a mortar with liquid nitrogen, with $1 \%(\mathrm{v} / \mathrm{v})$ polyvinylpyrrolidone (PVP), 5.0 $\mathrm{mL}$ of sodium acetate buffer $(0.1 \mathrm{M}, \mathrm{pH} 5.0)$ and $1 \mathrm{~mL}$ of EDTA (1 $\mathrm{mM}$ ). Extracts were centrifuged at $10,000 \mathrm{~g}$ for 10 minutes at $4^{\circ} \mathrm{C}$ and the supernatant was transferred to $1.5 \mathrm{~mL}$ tubes and stored at $-80^{\circ} \mathrm{C}$ (6) for the subsequent determination of peroxidase and phenylalanine ammonia lyase.

\section{Peroxidase Activity (E.C. 1.11.1.7)}

The estimate of the peroxidase activity was performed based on the assessment of the absorbance $\Delta$ supplied with guaiacol oxidation $\left(\mathrm{C}_{3} \mathrm{H}_{8} \mathrm{O}_{2}\right)$ in the presence of hydrogen peroxide (6). To develop the reaction, $50 \mu \mathrm{L}$ of guaiacol $(0.02 \mathrm{M}), 0.5 \mathrm{~mL}$ of hydrogen peroxide $(0.38 \mathrm{M})$ and $2.0 \mathrm{~mL}$ of phosphate buffer $(0.2 \mathrm{M} / \mathrm{pH} 5.8)$ were pipetted into a spectrophotometric cuvette. Next, $50 \mu \mathrm{L}$ of the enzymatic extract was added and gently agitated, and readings at the $470 \mathrm{~nm}$ wavelength were performed at 10 - second intervals for a period of one minute.

Data were transformed into $\sqrt{x+0.5}$ and subjected to analysis of variance, with averages compared through the Duncan test $(\mathrm{P}=0.05)$ using the SAEG program. 


\section{Phenylalanine Ammonia Lyase Activity (E.C. 4.3.1.5)}

Phenylalanine ammonia lyase (PAL) activity was assessed based on the absorbance difference resulting from the conversion of phenylalanine into trans-cinnamic acid (14). For such, aliquots of $1.5 \mathrm{~mL}$ of each enzymatic extract, $1.0 \mathrm{~mL}$ of the extraction buffer and $0.5 \mathrm{~mL}$ of phenylalanine (49.6 mg. $\mathrm{mL}^{-1}$ ), or distilled water for the blank test, were pipetted into test tubes. The mixture was incubated at $40^{\circ} \mathrm{C}$ for one hour and the enzymatic activity was stoped with an ice bath. Spectrophotometric readings were performed at the $290 \mathrm{~nm}$ wavelength.

Correlation between variables was assessed through the Pearson correlation analysis $(\mathrm{P}=0.05)$. Analyses were performed with the help of the SAEG program.

\section{RESULTS AND DISCUSSION}

\section{Physiological cost of resistance induction}

Only IL exhibited interaction between inducer and nitrogen levels (Table 1). Data on the behavior of the inducers in the two potting mixes revealed that only AM presented a significant difference between the substrates with and without the supplementation of nitrogen, with a greater IL in the former. Analysis of the interaction between the potting mix without nitrogen and the inducers revealed a significant difference only between ASM and AM, with the latter presenting greater IL. In the potting mix with nitrogen, there was no significant difference between the inducers, though all the treatments differed significantly from the control. In a study assessing the response of Arabidopsis to ASM application under the influence of different nitrogen concentrations as well as under conditions of competition between plants, it was observed that treated plants grew more slowly in the first week following the application of the resistance inducer. However, after this period, the plants compensated for the slow growth and began to develop more quickly than non-treated plants, though they remained smaller than the controls, especially in conditions of low nitrogen concentrations. In treatments with greater nitrogen concentrations, the induced plants became larger than the controls two to three weeks following treatments (8). According to the authors of the study, the reduction in seed production in comparison to the Control depended on the growing conditions.

Table 1. Internodal length (IL) in substrate without the addition of nitrogen $\left(\mathrm{N}_{1}\right)$ and with the addition of nitrogen $\left(\mathrm{N}_{2}\right)$, plant height $(\mathrm{H})$, shoot fresh weight $(\mathrm{SFW})$ and shoot dry weight (SDW) of cotton plants treated with acibenzolar-S-methyl (ASM), Agro-Mos ${ }^{\circledR}$ (AM) and jasmonic acid (JA), as well as untreated plants (control).

\begin{tabular}{llllll}
\hline \multirow{2}{*}{ Inducer } & \multicolumn{2}{c}{ IL (cm) } & H (cm) & SFW (g) & SDW (g) \\
\cline { 2 - 5 } & $\mathbf{N}_{\mathbf{1}}$ & $\mathbf{N}_{\mathbf{2}}$ & & & \\
\hline ASM & $8.72 \mathrm{cA}^{2}$ & $7.60 \mathrm{bcA}$ & $35.39 \mathrm{c}$ & $6.32 \mathrm{c}$ & $1.56 \mathrm{c}$ \\
AM & $11.02 \mathrm{abA}$ & $9.70 \mathrm{bB}$ & $39.98 \mathrm{~b}$ & $7.26 \mathrm{bc}$ & $1.93 \mathrm{~b}$ \\
JA & $9.27 \mathrm{bcA}$ & $9.63 \mathrm{bcA}$ & $40.66 \mathrm{ab}$ & $8.39 \mathrm{~b}$ & $2.53 \mathrm{a}$ \\
Control & $10.45 \mathrm{abcA}$ & $11.11 \mathrm{aA}$ & $42.96 \mathrm{a}$ & $9.71 \mathrm{a}$ & $2.20 \mathrm{~b}$ \\
C.V. (\%) & 9.49 & & 6.48 & 16.45 & 15.0 \\
\hline
\end{tabular}

${ }^{1}$ There was an interaction between the inducers and the different nitrogen levels

${ }^{2}$ Averages followed by lowercase letter in the same column and uppercase letter on the same line do not statistically differ from one another using the Duncan test $(\mathrm{P}=0.05)$.
There was a significant difference between the treatments and the controls for $\mathrm{H}, \mathrm{SFW}$ and SDW, regardless of the nitrogen levels in the potting mix (Table 1). Plants treated with ASM presented lower H, SFW and SDW, differing significantly from the control (Figure 1). However, the treatment with JA did not differ significantly from the control with regard to $\mathrm{H}$ and IL in the substrate that was not supplemented with nitrogen, and also presented greater SDW in comparison to the control (Table 1). In this respect, there was a significant difference between JA and the other inducers.

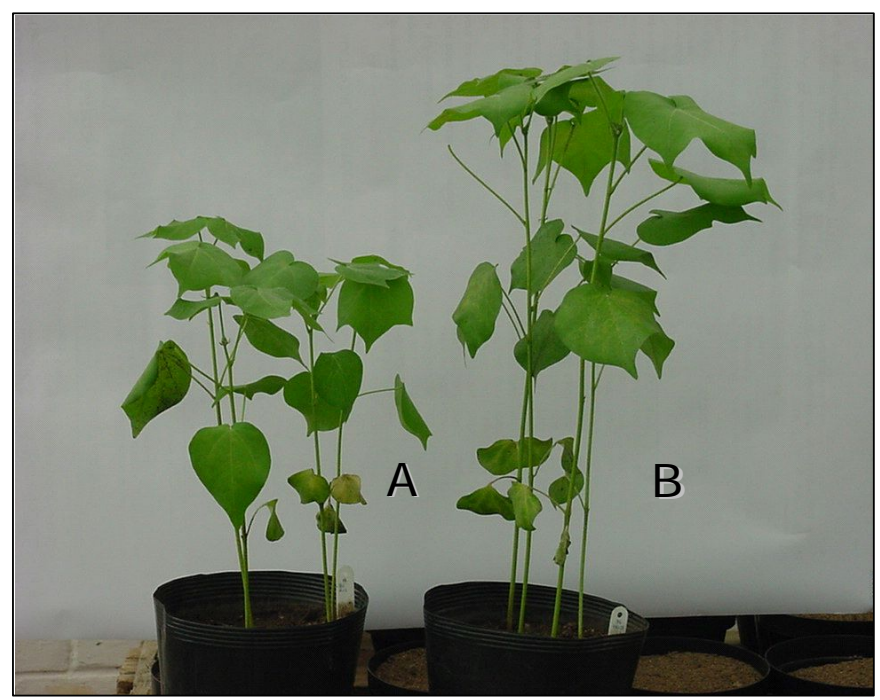

Figure 1. Comparison between a cotton plant treated with ASM (A) and control (B).

The effect of the physiological cost of ASM in plants has been reported in a number of studies $(4,8,12,15)$. According to Heil et al. (12), wheat plants treated with ASM presented lower gains in biomass and a lower number of spikelets and seeds in comparison to nontreated plants. This effect was more pronounced in plants subjected to low levels of nitrogen. According to the authors, differences between treated and non-treated plants possibly occurred due to metabolic competition between the processes involved in plant growth and the synthesis of defense compounds. Buzi et al. (4) observed that melon seeds treated with ASM germinated more slowly than non-treated seeds. In a study on the influence of the physiological cost of ASM in beans, Iriti \& Faoro (15) found no alterations with regard to electrophoretic patterns of proteins in seeds between treated and non-treated plants, nor any significant difference in seed production. The authors concluded that ASM-induced resistance does not cause an expressive physiological cost in beans.

The results obtained through induction of resistance with JA in the present study do not agree with results from other authors. According to Buzi et al. (4), melon plants treated with methyl jasmonate presented a pronounced delay in germination. The authors also observed that chemical treatments with inducers had a negative effect on the seedlings and growth rate of the root. The application of JA also caused a delay in fructification and a lower number of seeds in tomatoes. (20). A negative influence of methyl jasmonate on germination and plant growth is correlated with the synthesis inhibition of cell wall polysaccharides (18). It is possible that an increase in SFW and SDW, and not the difference between $\mathrm{H}$ and IL among plants treated with JA and the control, is due to differences between plant species tested in the present study and those tested in other studies, as there are no data on the influence of JA on cotton plants. 
Significant correlations $(\mathrm{P}=0.05)$ were observed among the most variables evaluated (Table 2). The greatest correlations were between SFW and SDW (0.94); IL and H (0.74); SFW and H (0.70); and SDW and $\mathrm{H}(0.70)$, indicating that any of these growth measures could be used to quantify physiological cost in cotton plants. The only nonsignificant correlations were between IL and RFW; IL and RDW; and $\mathrm{H}$ and RDW. According to Benincasa (3), growth measures are quite accurate, especially those that involve the shoot of the plant, which offer the ease of data collection and are useful in assessing growth and inferring the contribution of different physiological processes on vegetal behavior.

Table 2. Correlation coefficients between growth measures in cotton plants: internodal length (IL), plant height (H), shoot fresh weight (SFW), root fresh weight (RFW), shoot dry weight (SDW) and root dry weight (RDW).

\begin{tabular}{llllll}
\hline & H & SFW & RFW & SDW & RDW \\
\hline IL & $0.74^{*}$ & $0.30^{*}$ & -0.02 & $0.34^{*}$ & -0.004 \\
H & - & $0.70^{*}$ & $0.29^{*}$ & $0.70^{*}$ & 0.22 \\
SFW & & - & $0.47^{*}$ & $0.94^{*}$ & $0.35^{*}$ \\
RFW & & & - & $0.58^{*}$ & $0.66^{*}$ \\
SDW & & & & - & $0.43^{*}$ \\
\hline
\end{tabular}

* Pearson correlation coefficients at $5 \%$ probability.

\section{Enzymatic Determination}

There was an interaction between the substrates tested and PAL activity. However, only ASM differed significantly in the potting mixes, with lower activity in the mix without the addition of nitrogen (Table 3). In the potting mix with the addition of nitrogen, there was no significant difference between the inducers and the control. It is likely that the lack of difference in PAL activity between the treated plants and the control, as well as the lower activity in the ASMinduced plants in the substrate without nitrogen, was due to the period in which collection was carried out for the enzymatic determination, which was 20 days after the application of the inducer. PAL is involved in the initial step of propanoid synthesis and catalyzes the conversion of phenylalanine into trans-cinnamic acid, resulting in compounds such as flavonoids, phytoalexins and especially lignin, which bestows more resistance in the cell wall of plants with regard to pathogens (19). According to Chen et al. (5), peak PAL activity occurs between

Table 3. Phenylalanine ammonia lyase (PAL) activity in substrate without the addition of nitrogen (N1) and with the addition of nitrogen (N2) and peroxidase (POX) in cotton plants treated with acibenzolar-S-methyl (ASM), Agro-Mos ${ }^{\circledast}$ (AM) and jasmonic acid (JA), as well as untreated plants (control).

\begin{tabular}{|c|c|c|c|}
\hline \multirow[t]{2}{*}{ Inducer } & \multicolumn{2}{|c|}{$\begin{array}{c}\text { POX Activity } \\
\left(\Delta \mathrm{abs}_{470} \cdot \mathrm{min}^{-1} \cdot \mathrm{mg}\right)^{1}\end{array}$} & \multirow[t]{2}{*}{$\begin{array}{c}\text { POX Activity } \\
\left(\Delta \mathrm{abs}_{470} \cdot \mathrm{min}^{-1} \cdot \mathrm{mg}\right)\end{array}$} \\
\hline & $\mathbf{N}_{1}$ & $\mathbf{N}_{2}$ & \\
\hline$\overline{\mathrm{ASM}}$ & $3.50 \mathrm{bB}^{2}$ & $3.63 \mathrm{aA}$ & $0.84 \mathrm{a}$ \\
\hline $\mathrm{AM}$ & $3.61 \mathrm{aA}$ & $3.63 \mathrm{aA}$ & $0.73 \mathrm{c}$ \\
\hline JA & $3.65 \mathrm{aA}$ & $3.66 \mathrm{aA}$ & $0.74 \mathrm{c}$ \\
\hline Control & $3.65 \mathrm{aA}$ & $3.66 \mathrm{aA}$ & $0.78 \mathrm{~b}$ \\
\hline C.V. (\%) & 1.27 & & 5.57 \\
\hline
\end{tabular}

24 and 48 hours following induction. When enzyme activities related to plant defense were assessed, it was observed that both constitutive and ASM-induced enzymes were significantly lower under limiting nitrogen conditions (8).

Regarding peroxidase activity, no interaction was observed between substrates and inducers. Significant differences were only observed between the inducers themselves (Table 3 ). These results disagree with those found by Dietrich et al. (7), who observed a significant effect in the reduction of peroxidase activity when A. thaliana plants were cultivated in conditions of low nitrogen concentration.

The greatest peroxidase activity was obtained with ASM, which differed from the other treatments. The AM and JA treatments presented lower activity of the enzyme, not differing from each other, but differing significantly from the control. Peroxidase is an enzyme related to the defense mechanism of the plant and an increase in activity is frequently associated to the progressive incorporation of phenolic compounds in the cell wall during incompatible elicitor/plant-pathogen interactions (1). A number of authors have reported an increase in peroxidase activity with the use of inducers, thereby serving as an induced resistance marker $(1,2,4,8,21,22)$.

Physiological cost was observed in the treatment with ASM, for which resistance induction was confirmed with an increase in peroxidase activity. The treatments with AM and JA had no effect on PAL or peroxidase activities in cotton plants thereby making it impossible to analyze the physiological cost using these inducers.

\section{BIBLIOGRAPHIC REFERENCES}

1. Baysal, Ö.; Soylu, E.M.; Soylu, S. Induction of defense-related enzymes and resistance by the plant activator acibenzolar-S-methyl in tomato seedlings against bacterial canker caused by Clavibacter michiganensis subsp. michiganensis. Plant Pathology, Oxford, v.52, n.6, p.747-753, 2003.

2. Baysal, Ö; Turgut, C.; Mao, G. Acibenzolar-S-methyl induced resistance to Phytophthora capsici in pepper leaves. Biologia Plantarum, Praha, v.49, n.4, p.599-604, 2005.

3. Benincasa, M.M.P. Análise de crescimento de plantas (noções básicas). 2 ed. Jaboticabal: FUNEP. 2003. 41p.

4. Buzi, A.; Chilosi, G.; De Sillo, D.; Magro, P. Induction of resistance in melon to Didymella bryoniae and Sclerotinia sclerotiorum by seed treatments with acibenzolar-S-methyl and methyl jasmonate but not with salicylic acid. Journal of Phytopathology, Berlin, v.152, n.1, p.34-42, 2004.

5. Chen, Y.; Shin, J.; Liu, Z. Effect of light on peroxidase and lignin synthesis in mungbean hypocotyls. Plant Physiology and Biochemistry, New Delhi, v.40, n.1, p.33-39, 2002.

6. Dann, E.K.; Deverall, B.J. Activation of systemic disease resistance in pea by an avirulent bacterium or a benzothiadiazole, but not a fungal leaf spot pathogen. Plant Pathology, London, v.49, n.3, p.324-332, 2000.

7. Dietrich, R.; Ploss, K.; Heil, M. Constitutive and induced resistance to pathogens in Arabdopsis thaliana depends on nitrogen supply. Plant, Cell and Environment, Oxford, v.27, n.7, p.896906, 2004.

8. Dietrich, R.; Ploss, K.; Heil, M. Growth responses and fitness costs after induction of pathogen resistance depend on environmental conditions. Plant, Cell and Environment, Oxford, v.28, n.2, p.211-222, 2005.

9. EMBRAPA - Empresa Brasileira de pesquisa Agropecuária. Manual de métodos de Análise de Solos. 2 Ed. Centro nacional de Pesquisa do Solo. Rio de Janeiro, 1997, 21p.

10. Heil, M. Induced systemic resistance (ISR) against pathogens - a promising field for ecological research. Perspectives in Plant Ecology, Evolution and Systematics, Jena, v.4, n.2, p.65-79, 2001 .

11. Heil, M.; Baldwin, I.T. Fitness costs of induced resistance: emer- 
ging experimental support for a slippery concept. Trends in Plant Science, Oxford, v.7, n.2, p.61-67, 2002.

12. Heil, M.; Hilpert, A.; Kaiser, W.; Linsenmair, K.E. Reduced growth and seed set following chemical induction of pathogen defence: does systemic acquired resistance (SAR) incur allocation costs? The Journal of Ecology, Oxford, v.88, n.4, p.645-654, 2000.

13. Hoffland, E.; Niemann, G.J.; Van Pelt, J.A.; Pureveen, J.B.M.; Eijkel, G.B.; Boon, J.J.; Lambers, H. Relative growth rate correlates negatively with pathogen resistance in radish: the role of plant chemistry. Plant, Cell and Environment, Oxford, v.19, n.11, p.1281-1290, 1996.

14. Hyodo, H.; Kuroda, H.; Yang, S.F. Induction of phenylalanine ammonia-lyase and increase in phenolics in lettuce leaves in relation to the development of russet spoting caused by ethylene. Plant Physiology, v.62, n.1, p.31-35, 1978.

15. Iriti, M.; Faoro, F. Does benzothiadiazole-induced resistance increase fitness cost in bean? Journal of Plant Pathology, Bari, v.85, n.4, p.265-270, 2003

16. Kessler, A.; Baldwin, I.T. Plant responses to insect herbivory: the emerging molecular analysis. Annual Review of Plant Biology, Palo Alto, v.53, p.299-328, 2002.

17. McDowell, J.M.; Dangl, J.L. Signal transduction in the plant immune response. Trends in Biochemical Sciences, Amsterdam, v.25, n.2, p.79-82, 2000.

18. Miyamoto, K.; Oka, M.; Ueda, J. Update on the possible mode of action of the jasmonate: focus on the metabolism of cell wall polysaccharides in relation to growth and development. Physiologia Plantarum, Copenhagen, v.100, n.12, p.631-638, 1997.

19. Nakazawa, A.; Nozue, M.; Yasuda, H. Expression pattern and gene estructure of phenylalanine ammonia-lyase in Pharbitis nil. Journal of Plant Research, Tokyo, v.114, n.3 , p.323328, 2001.

20. Redman, A.M.; Cipollini Jr., D.F.; Schultz, J.C. Fitness costs of jasmonic acid-induced defense in tomato, Lycopersicon esculentum. Oecologia, New York, v.126, n.3, p. 380-385, 2001.

21. Shoresh, M.; Yedidia, I.; Chet, I. Involvement of jasmonic acid/ethylene signaling pathway in the systemic resistance induced in cucumber by Trichoderma asperellum T203. Phytopathology, St.Paul, v.95, n.1, p.76-84, 2004.

22. Stadnick, M.J.; Buchenauer, H.; Inhibition of phenylalanine ammonia-lyase suppresses the resistance induced by benzothiadiazole in wheat to Blumeria graminis f.sp. tritici. Physiological and Molecular Plant Pathology, Minneapolis, v.57, n.1, p.25-34, 2000 .

23. Vallad, G.E.; Goodman, R.M. Systemic acquired resistance and induced systemic resistance in conventional agriculture. Crop Science, Madison, v.44, n.6, p.1920-1934, 2003.

24. Walters, D.; Walsh, D.; Newton, A.; Lyon, G. Induced resistance for plant disease control: maximizing the efficacy of resistance elicitors. Phytopathology, St. Paul, v.95, n.12, p.1368-1373, 2005. 